\title{
The Determinants of Deposit Growth in Case of Commercial Banks in Ethiopia
}

\author{
Habtamu Alebachew* Anwar Adem \\ Lecturer at Department of Accounting and Finance Dire Dawa University, Dire Dawa, Ethiopia
}

\begin{abstract}
Deposits are the foundation upon which Banks prosper and grow. And deposit is engine to financial institution operations due to the fact maximum companies in rising markets depend closely on financial institution loans as a supply of financing. So, this study investigates bank-specific variables and macro-economic determinant of commercial banks deposit growth in Ethiopia. Macro-economic factors consider under this study were age dependency ratio, unemployment rate, population growth, broad money supply and Inflation. While bank specific variables included were branch expansion and bank size. Eight commercial banks have been the subject for the study by incorporating a 10 years' data ranging from the period 2010 to 2019. A quantitative research approach and explanatory design were adopted in carrying out this research. The study had employed fixed effect panel data estimation techniques to analyse the influence of bank specific and macroeconomic factors on deposit growth using Eviews 10. The results of regression analysis showed that branch expansion, bank size, broad money supply and inflation have a positive and significant effect on deposit growth of commercial banks. On the other hand, Age dependency ratio and population growth have negative and statistically significant effect on deposit growth. Finally, the study recommends there should be stable inflation, a healthy money supply and population growth and branch expansion.
\end{abstract}

Keywords: Deposit, Commercial banks and Fixed effect.

DOI: $10.7176 /$ RJFA/12-19-03

Publication date:October $31^{\text {st }} 2021$

\section{Background of the study}

Banks play an important role in economic development by bridging the gap between the surplus and deficit fund sectors (Yakubu and Abokor, 2020). Commercial banks are financial institutions that accept deposits and make loans as their primary purpose, facilitating the flow of funds in the economy (Kassa, 2017). Commercial banks often play an important role in the exchange and payment systems, lowering transaction costs and improving convenience. Commercial banks are recognized in developing economies for their critical role in enabling the economy to continue to meet the ever-increasing demand for credit (Teshome, 2017). In countries like Ethiopia, where the banking industry dominates the financial sector, the bank's successful and productive operation plays a critical role in accelerating economic development (Bargicho, 2015).

Pitonakova (2016) asserts that bank deposits are made to deposit accounts such as savings accounts, checking accounts, and time deposit accounts. According to Gunasekar and Kumari, (2018) it is the most important factor for the survival of commercial banks and is critical to the economy's long-term viability. Also, Yakubu and Abokor (2020) said that it's far an engine to financial institution operations due to the fact maximum companies in rising markets depend closely on financial institution loans as a supply of financing. Thus, in order for commercial banks to lend, there must first be deposits in their treasury.

According to Mahdi and Mohammed (2010) financial resources of banking systems are primarily provided from customer's deposit. As a result, the going concerns of every commercial banks is highly relying on deposits collected from customers. Low level of deposit growth in commercial banks lead to inability to disburse loans, unable to cover operation costs, to pay debts, unstable board of directors due to frequent reshuffle as disgruntled members vote officials out, quitting of members to competitors (T/tsadik, 2019). Therefore, managing and controlling deposits is essential for commercial banks in general to be competitive, effective in operation and to attract customers.

In today's world, the concern of bank resource (deposit) has become one of the most important and crucial in the field of business due to the greater ineffectiveness of lots commercial banks in the world in terms of their operation and its unfortunate effect on their performance. According to Simegnew (2020) lack of enough deposits in banks' treasury or inability to pay operational costs and unable to satisfy customers resulted in a failure for the banking industry before, during and after the financial crisis of 2007-2009 in all over the world. For instance, in USA and other developed countries several commercial banks were failed due to poor deposit growth, these includes Southern Pacific Bank, Dollar Savings Bank, Metropolitan Savings Bank, First Integrity Bank, NA, The First State Bank, City National Bank of New Jersey, Highland Community Bank and so on (FDIC, 2019). Banking crises can have long-lasting adverse effects on deposit growth (FDIC, 2010).

In Ethiopia, there is an increasingly growing public and private investment in the area of different sectors. For example, infrastructure, agriculture, manufacturing, and processing etc. which seeks for continues supply of 
large amount of finances. So, bank plays the intermediation functions in the efficient allocation of those resources to demanding sector (Gerawerk, 2016). According to NBE (2019/20) annual report the total deposit was 1.04 trillion having a share of Ethiopian private commercial banks was $42.6 \%$ as compare to Commercial Bank of Ethiopia (CBE) which had approximately $57.4 \%$ total deposit share in the country.

Generally, the issue of commercial bank's deposit growth and its determinants are crucial to the financial sector of developing country like Ethiopia. Thus, this study enables banks and regulators to keep control to the issue of deposit growth which is very important to the security of their operation as well as the economy as a whole in the country. Therefore, this study examined the determinants of deposit growth of Ethiopian state owned and private commercial banks.

\section{Statement of the problem}

For all intents and purposes, its industry is closed and generally less developed than its regional peers and that the banking business performance depends on their resources (deposit) (T/Tsadik, 2019). One of the bank resources is mobilized deposit, which facilitates various country level as well as individual level investment at most. Ethiopian commercial banks have a great role to support financial gaps of the all business and Government project but it is not sufficient to fill those gap. This problem is arises from very low level of deposit in commercial banks (Gebre, 2019). In Ethiopia the concern for deposit growth by commercial banks were an important aspect in the recent time. According to the report by national bank of Ethiopia (2020); the total amount of deposit in a bank were 1.04 trillion of this the share of private commercial banks were $42.6 \%$ and the remaining $57.4 \%$ of the deposit was shared by public banks (NBE, 2020). Even if, in 2018 the total amount of deposit mobilized through commercial banks reached 730 billion (33\% of GDP) Commercial banks have increased their total credit to the public and private sector by about 12-fold over the past decade, from Birr 67 billion to Birr 740 billion this indicates even the mobilized fund/deposit is not sufficient to meet the loan requirement (Cepheus, 2019). So the general objective of this study is to examine the determinants of commercial bank's deposit growth in Ethiopia. Specifically, to examine the effect of bank specific and macroeconomic variables on deposit growth of commercial banks.

While taking into account of very little about the determinants of deposit growth in Ethiopian particularly in private banks, this study attempts to supplement the empirical evidence by incorporating both public and private commercial banks. As it is observed from empirical reviews there was a problem of consistency in some of the explanatory variables. In addition, to the above gap this study the effect of bank size and unemployment rate on deposit growth were considered which did not examine by the above researchers in Ethiopia. Generally, as the concern of deposit were a critical issue for prosper continuation of a nation. This study wants to fill the above literature gap by a detail investigation of factors determining deposit growth of commercial banks (public and private) in Ethiopia. The objectives of the study were to examine the effect of bank specific variables on deposit growth of commercial banks and to examine the impact of macro-economic variables on deposit growth of commercial banks.

\section{Review of related literature}

Deposit is one of the resources commercial banks highly motivated to mobilize and the most liquid money that is found in the treasury of banks and which is ready to be borrowed in need of the fund (James and Tories, 2008). Deposit mobilization is the major activities of commercial banks. According to Mahdi and Mohammad (2010), financial resources of banking systems are naturally provided from people's deposit. The functions of commercial banks of Ethiopia is clearly stated at Art 2 sub Article 2 of the Banking Business Proclamation No $592 / 2000$. Accepting deposits is one of the primary functions of commercial banks in Ethiopia. The commercial banks accept deposit of their customers. The customers deposit in the commercial banks to be safe and secure their many and to be free from theft and robbery. Specially, in this time people have developed culture of saving and they use even ATM method to make commerce in any super market or any other markets where such services are provided.

There are three types of deposits, Current account deposits Such deposits are payable on demand and are, therefore, called demand deposits. These can be withdrawn by the depositors any number of uptimes depending upon the balance in the account. Fixed deposits (Time deposits) Fixed deposits have a fixed period of maturity and are referred to as time deposits. These are deposits for a fixed term, i.e., period of time ranging from a few days to a few years. These are neither payable on demand nor they enjoy cheque facilities. Savings account deposits These are deposits and its main objective is to save. Savings account is most suitable for individual households. Deposits are the foundation upon which Banks thrive and grow. They are a unique item on banks' balance sheet that distinguishes it from other types of business firms. 


\section{Purpose of deposits}

\section{Deposits as a source of fund for loan}

Herald (2009) states deposits are the main source of banks to provide loan. This deposit is mainly provided by people as Mohammad and Mahdi (2010). However, deposits can also be provided by business organizations, NGOs, government and so on. Therefore, whether deposits are from individuals, businesses and government they are important financial source of banks.

\section{Focusing on deposit is cheaper than raising equity}

Banks as any other business organizations can collect funds from debt and/or equity. In the banks context, raising equity is more expensive or costly than attracting deposits. Lorenzo et al (2010) states that, if the lending channel plays a role, the deposit growth should lead to an increase in the supply of loans due to the additional source of financing for banks

\section{Banks make profit using their deposits}

Mahendra (2005) said that deposits provide most of the raw materials for bank loans and thus represent the ultimate source of the bank's profits and growth. Banks make profit by using their deposits, therefore it is said that depositors can disciple banks.

\section{Fund investment and/or development projects}

Debt is largely held by domestic commercial banks which are funded mainly from deposits, the government demand for bank assets enabled banks to continue to expand their deposit base rapidly and profitably (Herald and Heiko, 2009). Individual investors and government are mainly depending on the deposits of banks to fund their investments and/or development projects.

Banks' management major concern is the variability of deposits for several reasons. (George 1972) mentioned the reasons why the variability of banks' deposit is important as follows: -

$>$ Deposit variability is frequently included as an important cause of portfolio strategy. The more volatile a bank's deposits are the more liquid its mix of assets will be.

$>$ To the extent deposit variability affects bank holdings of cash and excess reserves, variability affects the distribution of total member bank reserves within the banking system and thereby the path and speed of monetary policy actions.

$>$ To the extent deposit variability affects the mix of banks assets; it affects the availability of funds for loans and consequently the loan rate.

\section{Theories of saving (deposit) \\ The Classical Theory of Interest}

The classical theory of interest rate is associated with the names of David Ricardo, Marshall, A.C. Pigou, Cassels, Walras, Taussing and Knight. This theory is also known as the real theory of interest rate because in determination of interest rate only real factors like productivity and thrift are considered and monetary factors are not given any importance. According to the classical theory, the rate of interest rate is determined by the intersection of demand for money and supply of money. Interest is the price of investment because firms borrow money for investment. Thus, household save their money to earn interest rate. According to this theory, High interest rate leads to high saving and low interest rate leads to low saving. Thus, saving is directly (or positively) related to interest rate. Firms' demand for investment is fulfilled by households' saving. Thus, interest rate in goods market is determined at the point where both supply of saving and demand for investment crosses each other or intersect each other. In classical theory, saving is an increasing function of rate of interest, which may be written as $\mathrm{S}(\mathrm{r})$.

\section{Neo-Classical Growth Theory}

Theoretically, there is controversy on the relationship between inflation and saving. Mundell (1963) and Tobin (1965) have fruitfully explained the effect of inflation on economic growth and saving based on Neo-Classical Growth Theory. They believe increased nominal interest caused by inflation will make people option to save and investment instead of consumption. This will result in increasing capital accumulation which will stimulate saving and economic growth. Mundell (1963) and Tobin (1965) depict a positive relationship between inflation and saving. Contrary to the conclusion of the Mundell-Tobin Effect, Stockman (1981) develops a long-run equilibrium growth model with assumption of "cash-in-advance constraint". In the model of Mundell (1963) and Tobin (1965), real money balances and investment are substitution. But in the model of Stockman (1981), the two variables' relationship is complemented, there is a negative relationship between the steady-state level of output and the inflation rate. Stockman's insight is prompted by the fact that firms put up some cash in financing their investment projects. Sometimes the cash is directly part of the financing package, whereas other times, banks require compensating balances. Stockman models this cash investment as a cash-in-advance restriction on both consumption and capital purchases. Since inflation erodes the purchasing power of money balances, people reduce their purchases of both cash goods and capital when the inflation rate rises. Correspondingly, the steady- 
state level of output falls in response to an increase in the inflation rate (Malla, 1997). If the incomes are not indexed, unanticipated inflation will cause unanticipated cuts in the real income and hence decreased the saving rates. Also, high inflation can increase the opportunity cost of holding money and increase the rewards for the search activities in shopping wasting real resources and thereby reducing savings (Miller and Benjamin, 2008). As against this, another theory proposes that if the real income is correctly anticipated either by indexation or wage inflation, unanticipated inflation will increase the saving rate. Inflation is a good proxy for macroeconomic uncertainty. Higher uncertainty/higher inflation induces people to save a larger portion of their money for precautionary motives.

\section{Life-Cycle Hypothesis Theory}

Ando and Modigliani (1963) postulate a life-cycle hypothesis of consumption of an individual in a specified period of time. The life-cycle hypothesis has been utilized extensively to examine savings and retirement behavior of older persons. This hypothesis begins with the observation that consumption needs and income are often unequal at various points in the life cycle. Younger people tend to have consumption needs that exceed their income. Their needs tend to be mainly for housing and education, and therefore they have little savings. In middle age, earnings generally rise, enabling debts accumulated earlier in life to be paid off and savings to be accumulated. Finally, in retirement, incomes decline and individuals consume out of previously accumulated savings. This model suggests that in the early years of a persons' life they are net borrowers. In the middle years, they save to repay debts and provide for retirement. The life cycle model predicts that a higher interest rate increases the current price of consumption vis-à-vis the future price, thus leading to an increase in savings. According to Tochukwu, Nwachukwu, and Peter (2009), the life-cycle hypothesis theory is more focus on what happens in developed economies but little or no regard to the peculiarities of developing countries. So, it needs to modelled separately from that in developed economies because

* Households in developing countries tend to be larger than those in developed ones, and there is a greater tendency for several generations to live together. Such a household has no need for retirement saving because resources are shared between workers and dependents, and ownership is passed from parents to children. This kind of household can internalize many of the insurance activities that would otherwise require saving.

\section{Empirical literatures}

Yakubu and Abokor (2020), aims to examine the key factors determining bank deposit growth in Turkey for the period 2000-2016. The study employs the autoregressive distributed lag approach to investigate the effect of bank-level and macroeconomic factors on deposit growth. The results reveal that bank stability, banking sector efficiency, broad moneysupply, economic growth, and inflation are significant determinants of deposit growth in the long run. The findings further show that in the short run, only branch expansion and broad money supply are relevant for bank deposit mobilization.

Ünvan and Yakubu (2020), assess the drivers of bank deposits in Ghana for the period 2008-2017 by applying Random effect. Controlling for macroeconomic factors, the results show that profitability, bank size, and liquidity are significant determinants of bank deposit. Macroeconomic instability proxied by inflation also exerts a negative significant impact on bank deposit. The findings further reveal that an increase in banks' capital adequacy level does not essentially translate into deposit.

Simegnew (2020), One regression equation was used to test the hypotheses constructed in relation to both macro-economic and bank-specific determinants and deposit growth by using STATA statistical software. And his result shows real GDP growth, deposit interest rate, inflation, population growth and branch expansion rate are positive and significant while the exchange rate is positively related but its effect were insignificant.

Gebre (2019), aims to find determinants of private commercial banks deposit growth in Ethiopia.From a year between 2008 up to 2017 by using both descriptive and econometric analysis based on a panel data. In conducting all the data analysis, the study used EViews 8 software. And the result of the estimation shows number of branch, GDP and company age have a posetive and siginificant effect on deposit growth of commercial banks but, deposit interest rate has a negative relationship with deposit growth having a siginificant effect on the deposit growth of private commercial banks.

Islam et.al (2019), examine the impact of firms-specific variables and macroeconomic variables on the deposit mobilization of private commercial banks in Bangladesh using panel data regression methodology. company size has significant negative impact on the deposit mobilization and broadly growth rate has significant positive impact on the banks deposit growth rate whereas the rest of the selected variables i.e. number of banks branches, deposit interest rate, loan-to-deposit ratio, Gross Domestic Products (GDP) growth rate, inflation rate have no significant impact on the banks deposit growth rate of the private commercial banks in Bangladesh.

Ferrouhi (2017), This paper aims to define the determinants of bank deposits in Morocco for the period 20032014 using panel data regression. To test the panel data stationarity, he used three tests : Levin, Lin and Chu test, Breitung test and Im, Pesaran and Shin test. The results of the study show that Moroccan banks' deposits are 
explained by four banks specific determinants (Banks size, internal funding, external funding and interest rate on deposits) and one macroeconomic variable (unemployment). And conclude that deposit level were mainly affected by the both variables.

Ambe (2017), conduct a cross-sectional study on Investigation of Determinants of Deposit Mobilization in Commercial Banks of Ethiopia using a time series data of 20 years 1995 - 2014. And it based on causual research design by applying multiple regression model. The multiple linear regression output showed that loan, number of customers, expansion of new branches and emergence of new competitors had significant effect on resource mobilization through customer deposit. Though, number of competitors had negative effect. On the other hand interest rate had positive effect on resource mobilization through customer deposit. Though, it is statistically insignificant.

Abebe (2017), assess Factors affecting banks deposit growth in case of commercial bank of Ethiopia (CBE) from $1981 / 1982$ to $2015 / 2016$ fiscal period. By using primary and secondary source of to collect data's and he uses SPSS (Statistical Package for Social Sciences) software to examine questionnaires and describe the outcome of using both qualitative and quantitative data. The study shows inflation, GDP and deposit interest rate was found to have a positive relationship with bank deposit growth although the weight on deposit growth is insignificant and branch opening has positive correlation with deposit mobilization and deposit progress in connection with increasing number of customer.

Teshome (2017), tried to examines the commercial banks deposit with reference to Ethiopian commercial banks. He used mixed research approach to achieve the study objective. The study used semi structured personal interview from the employees of sampled commercial banks of Ethiopia. Regarding to quantitative data the study referenced to Ethiopian commercial banks on basis of data covers sixteen years (1999/2000-2014/2015). He has taken eight commercial banks of Ethiopia as a sample out of eighteen commercial banks by using purposive sampling technique. The result of this study from using random effect panel least square regression exhibited that number of branches, deposit interest rate, loan to deposit ratio, annual inflation rate, real gross domestic product and population number were significant relationship with commercial banks deposit. Results from interview social awareness and regulation of anti-money laundry and counter financial terrorism have an effect on commercial banks deposit.

Turhani and Hoda (2016), examine The Determinative Factors of Deposits Behavior in Banking System in Albania from 2005 - 2014. They assess the impact of macro economic, bank specific variables and banking crisis by using dichotomous variable on deposit performance by applying SPSS 20.0 and descriptive analysis. The study revealed that period of macro economic crisis, exchange rate exposure, bank liquidity and unemployment rate have a positive significant effect on deposit of banks. In contrary to this inflation, interest rate, cash out side bank and capitalization have a negative significant effect on the deposit performance.

Pitonakova (2016), assess the determinants of Household Bank Deposits: Evidence from Slovakia from quarterly data 1998 - 2015 quarterly data using ARDL methodology. The results show that real interest rate, elderly dependency ratio, inflation and gross disposable income boost up deposits, while income growth reduces household deposits.

Gerawork (2016), also investigates the factors that affect deposit mobilization and the associated costs of deposit mobilization in Ethiopian private banks. This study adopts mixed approach to gather the data. He gathered primary data using questionnaire. This study used purposive sampling technique to collect data from primary sources. This study used also the secondary sources of data from annual reports of all private commercial banks of Ethiopia, data from National Bank of Ethiopia (NBE) and from Central Statistical Authority (CSA). This study used time series data from 2000-2014 for analysis made using Classical linear regression method. The result of the study reveals that Age dependency ratio, Investment and money supply, are the most significant factors of deposit mobilization activity. The other variable such as Per capita income has insignificant power to influence the dependent variable.

Larbi-Siaw and Lawer (2015), investigated the drivers of bank deposits in the context of Ghana by Employing a Co-integration analysis and Fully Modified Ordinary Least Square (FMOLS) from the year 2000 - 2013. The findings revealed an inverse relationship between inflation rate and money supply in the short run. Monetary policy, however, showed a direct impact on deposit in the shor trun. The study also evidenced that in the longrun, money supply directly explains deposit level, while the effect of interest rate and inflation is negative.

From the above researches it is observed that bank deposit growth was determined by macro-economic and bank specific variables. But from their findings it is observed there was no generally accepted relationship between commercial bank deposit growth and its determinants.

To the knowledge of the researcher there were a few studies conducted in this area in Ethiopia, most of them focus on private commercial banks. And this study differs from previous researches by studying on both public and private commercial banks. This study also wants to examine the effect of unemployment rate and bank size on deposit growth of commercial banks in Ethiopia. 


\section{Research Methodology}

Research design and Approach

The study employed quantitative research approach and explanatory research design by using balanced panel data to see the regression result analysis with respective to empirical literatures on the determinants of deposit growth of commercial banks.

Total population of the study; The total population of study includes all commercial banks operating in Ethiopia. According to NBE report, there are sixteen privately owned commercial banks and one publicly owned commercial bank at the end of June 30, 2019.

Sampling; the study used purposive sampling by considering the availability of full data for the selected time period. The study takes eight commercial banks (both private and public) as the sample frame to drawing sample size to the research. The study takes 8 commercial banks with 10 years' data from 2010 to as of June 30, 2019.

Data type and source; structured document analysis was used for this research to collect required information, which was relevant for addressing the objective of the study. Data were collected from audited financial statements (income statement and balance sheet) of each commercial banks included in the sample and various journals and publications of NBE and MOFED for the macroeconomic data from 2010 to 2019. All data that were collected and figures for the variables are expressed as of June 30th of each year under study on annual base.

Data presentation and analysis; The researcher performs diagnostic tests to ensure whether the assumptions of the classical linear regression model (CLRM) are violated or not. In conducting all the data analysis, the study had used Eviews 10 software package.

\section{Model Specification}

In order to investigate the determinants of bank specific and macro-economic factors of commercial banks' deposit growth, the general multivariate regression model was adapted.

$Y$ it $=\alpha+\beta X$ it $+u$ it

The subscript $\mathrm{i}$ denote the cross- section and t represent the time-series dimension. The left hand variable Yit is the dependent variable, $\alpha$ is intercept term, $\beta$ is coefficient which represents the slope of the explanatory variables and $X i t$ is a vector of the explanatory variables for bank $\mathrm{i}$ in time $\mathrm{t}, \mathrm{t}=1 . \mathrm{T} ; \mathrm{i}=1 \ldots \ldots, \mathrm{N}$ and uit is the error term

Therefore, the general model which incorporates all of the variables to test hypotheses of the study were; DEPGRit $=\beta 0+\beta 1$ (ADRit) $+\beta 2$ (INFit) $+\beta 3$ (POPGit) $+\beta 4$ (UNEit) $+\beta 5$ (M2it) $+\beta 6($ BSit $)+\beta 7($ BREit $)+$ cit................................ 3.1

Where;

DEPGDRit : is deposit growth of $i^{\text {th }}$ bank at time $t$

ADRit: is the Age dependency ratio of Ethiopia on year $t$

INFit: is the inflation rate in Ethiopia in year $t$

POPGit: is population growth rate at time $t$

UNEit: is the annual unemployment rate at time $t$

M2it: is broad money supply at time $t$

BSit: Natural logarithm of total assets of $i^{\text {th }}$ bank on the year $t$

BREit: is branch expansion rate of $i^{\text {th }}$ bank on the year $t$

$\beta 0$ : is constant

$\beta 1$ - ------- $\beta$ : are parameters to be estimated

cit- is error term

Data Analysis

\section{Testing Assumptions of Classical Linear Regression Model (CLRM)}

The study has conducted diagnostic tests to guard against the possibility of obtaining and interpreting spurious regression results. In the way to make sure the model is valid, consistent and reliable the researcher has applied the following tests and the results of the tests are presented in the following sections.

\section{Normality Test}

In linear regression analysis this tested with Jarque -Bera normality test of residuals. According to Brooks (2008), if the residuals are normally distributed, the histogram should be bell shaped, the kurtosis must be no by far large from the 3 and Bera-Jarque probability statistics/P-value is also expected not to be significant. This means that the P-value given at the bottom of the normality test screen should be greater than 0.05 not to reject the null hypothesis of normality at 5\% significance level (Brooks, 2008). The hypothesis of the normality test was formulated as follows:

H0: The data are normally distributed. 
H1: The data are not normally distributed. $\alpha=0.05$

Decision Rule: Reject H0 if p-value less than significant level. Otherwise, do not reject H0

Figure 4.1. Normality Test

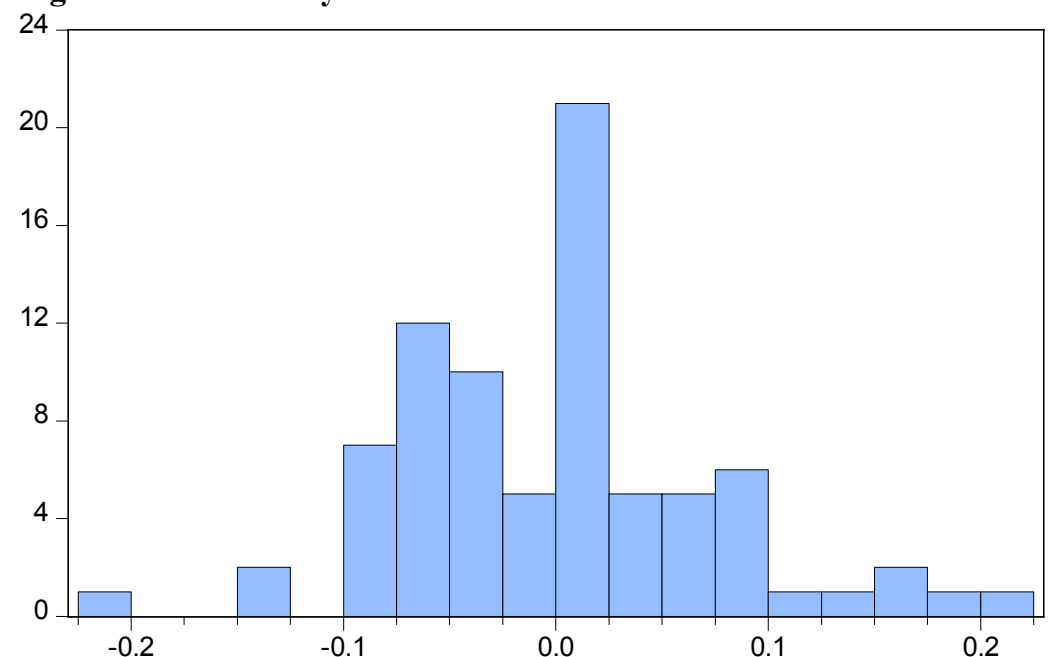

Series: Standardized Residuals

Sample 20102019

Observations 80

$\begin{array}{lr}\text { Mean } & -4.51 \mathrm{e}-18 \\ \text { Median } & 0.000937 \\ \text { Maximum } & 0.217531 \\ \text { Minimum } & -0.211920 \\ \text { Std. Dev. } & 0.074421 \\ \text { Skewness } & 0.356597 \\ \text { Kurtosis } & 3.735457\end{array}$

Jarque-Bera 3.498473

Probability $\quad 0.173907$

\section{Source; Eviews 10 and researcher own computation}

As shown above, the Bera- Jarque statistics have a P-value of 0.173907 clearly implies that it is greater than 0.05 , which indicates there is no evidence for the presence of an abnormality in the data. Thus, the null hypothesis that the data is normally distributed should not be rejected since the P-values were in excess of 0.05 significant levels. It can be concluded that there is no problem of normality.

\section{Test for Multi-co linearity}

When independent variables are multi collinear, there is overlapping or sharing of predictive power. Thus, if multi co-linearity is perfect, the regression coefficients of the independent variables are undetermined and their standard errors are immeasurable Gujarati, (2004). As noted by Gujarati, (2004), a serious problem for multi colinearity is occurred if the correlation is about 0.8 or larger so, if pair-wise or zero-order coefficient between two explanatory variables is out of the recommended range of multi co-linearity which is -0.8 or 0.8 . Accordingly, the results of the test for existence of multi co-linearity among seven of the independent variables are presented in the correlation analysis matrix here below.

\begin{tabular}{|c|r|r|r|r|r|r|r|}
\hline Correlation & ADR & BRE & BAS & UNEM & POP & M2 & INF \\
\hline ADR & 1.000000 & & & & & & \\
\hline BRE & -0.238827 & 1.000000 & & & & & \\
\hline BAS & -0.330643 & -0.096839 & 1.000000 & & & & \\
\hline UNEM & 0.773145 & 0.000556 & -0.341324 & 1.000000 & & & \\
\hline POP & 0.034652 & 0.035955 & -0.112948 & 0.114389 & 1.000000 & & \\
\hline M2 & 0.750419 & -0.239168 & -0.204253 & 0.408141 & 0.056461 & 1.000000 & \\
\hline INF & 0.507497 & -0.284030 & -0.091057 & 0.210063 & -0.037914 & 0.589797 & 1.000000 \\
\hline
\end{tabular}

\section{Source; researcher own computation}

The results in the above correlation matrix show that the highest correlation of 0.773 between Age dependency ratio and unemployment rate and 0.75 between age dependency ratio and Broad money supply. Thus, there was no such series pair-wise correlation that exceeds 0.8 which suggests there is no serious problem of multi co-linearity or the results showed that the problem of multi co-linearity did not exist among the explanatory variables in the study model.

\section{Autocorrelation Test}

Here, it is assumed that the errors are uncorrelated with one another. If the errors are not uncorrelated with one another, it would be stated that they are 'auto-correlated' or that they are 'serially correlated'. The study uses Durbin-Watson test (DW test) to test autocorrelation. 


\begin{tabular}{|l|l|l|l|l|}
$\begin{array}{l}\text { Auto correlation test } \\
\text { Reject H0: positive } \\
\text { autocorrelation }\end{array}$ & $\begin{array}{l}\text { Inconclusive } \\
\begin{array}{l}\text { Do not reject H0: } \\
\text { no evidence of } \\
\text { autocorrelation }\end{array}\end{array}$ & Inconclusive & $\begin{array}{l}\text { Reject H0: negative } \\
\text { autocorrelation }\end{array}$ \\
\hline 0 & $\mathrm{dL}$ & $\mathrm{dU} \quad 2$ & $4-\mathrm{dU}$ & $4-\mathrm{dL}$
\end{tabular}

Source: Brooks (2008) Durbin Watson statistic

The study used the $\mathrm{dL}$ and $\mathrm{dU}$ values for 80 observations as approximation of 80 observations. As per the DW table in the figure above for 80 observations with seven explanatory variables at $1 \%$ level of significance, the $\mathrm{dL}$ and $\mathrm{dU}$ values are 1.36 and 1.62 respectively. The values of $4-\mathrm{dU}=4-1.62=2.38 ; 4-\mathrm{dL}=4-1.36=2.64$. The Durbin-Watson test statistic of 2.25 is clearly between the upper limit (dU) which is 1.62 and the critical value of 4-dU i.e.2.38 and thus the null hypo thesis of no autocorrelation is within the non- rejection region of the number line and thus there is no evidence for the presence of autocorrelation.

\subsubsection{Heteroscedasticity Test}

It is assumed that the error terms are homoscedastic, i.e., it assumed that the error terms have a constant variance otherwise they are said to be heteroskedastic. To ensure that this assumption is no longer violated, the most popular method, the white test has to be and made Brooks (2008) recommended that not to reject the null hypothesis, the p-value of the F- and $\chi^{2}\left(, \mathrm{LM}^{\mathrm{ce}}\right)$ versions of the test statistic and the p-value of the Scaled Explained SS must be higher than 0.05 .

The hypothesis of the heteroscedasticity test was formulated as follows;

H0: There is no Heteroscedasticity problem in the model.

H1: There is Heteroskedasticity problem in the model. $\alpha=0.05$

Decision Rule: Reject H0 if p-value less than significant level. Otherwise, do not reject H0.

\section{Heteroscedasticity test}

Heteroscedasticity Test: White

\begin{tabular}{llll}
\hline \hline F-statistic & 0.875153 & Prob. F(24,55) & 0.6308 \\
Obs*R-squared & 22.10807 & Prob. Chi-Square(24) & 0.5728 \\
Scaled explained SS & 32.01699 & Prob. Chi-Square(24) & 0.1266
\end{tabular}

Source; researcher own computation

The above table presents three different types of tests for heteroscedasticity indicating that the $\mathrm{F}$ - and $\chi^{2}$ $\left(, \mathrm{LM}^{\mathrm{ce}}\right)$ versions of the test statistic give the same conclusion that there is no evidence for the presence of heteroscedasticity, since the p-values are higher than 0.05 . The third version of the test statistic, „Scaled explained $\mathrm{SS}^{\mathrm{ee}}$, as the name suggests is based on a normalized version of the explained sum of squares and also suggests that there is no evidence of heteroscedasticity as its p-value is reasonably higher than 0.05 and not significant.

\section{Model Specification Criteria}

According to Gujarati (2004) cited in Mekbib (2016), if the number of time series data is large and the number of cross-sectional units is small, there is likely to be little difference in the values of the parameters estimated by fixed effect model. So that in this studies the number of Cross Section units (8) less than the number of time series (10 years). Therefore, fixed effect model is more appropriate than random effect model for this study.

\subsection{Test for Model Specification: Ramsey RESET Tests}

The assumption of the CLRM that the econometric model used in the analysis is correctly specified has two meanings. The first is since the model is correctly specified, there is no equation specification error and the second is no model specification error. When the appropriate variables are omitted from a model, the OLS estimators of the variables retained in the model are biased and inconsistent. In addition to the above, the variance and standard error of these coefficients are incorrectly estimated. As a result, including of irrelevant variables in the model are also that the estimated variances tend to be larger than necessary, thereby making for less precise estimation of the parameters. Therefore, in order to select a correct estimated model, the researcher has carried out the Ramsey-RESET Test to check on the model specification. The hypothesis of the model specification test formulated as follows;

$\mathrm{H} 0$ : The model is correct.

H1: The model is incorrect. $\alpha=0.05$

Decision Rule: Reject H0 if p-value less than significant level. Otherwise, do not reject H0

Ramsey RESET Test

Equation: UNTITLED 
Specification: DEPGR BRE ADR BAS INF M2 POP UNEM C

Omitted Variables: Squares of fitted values

\begin{tabular}{lccc}
\hline \hline & Value & Df & Probability \\
\cline { 2 - 4 } t-statistic & 1.298124 & 71 & 0.1984 \\
F-statistic & 1.685126 & $(1,71)$ & 0.1984 \\
Likelihood ratio & 1.876552 & 1 & 0.1707 \\
\hline \hline
\end{tabular}

Source; Eviews 10 and researcher own computation

As it can be seen from $\mathrm{t}, \mathrm{F}-$ and $\chi^{2}$ versions of the test which are presented in the above rows respectively, there is limited evidence for non-linearity in the regression equation (the p-values indicate that the test statistics are insignificant even at the $10 \%$ ). So it would be concluded that the model specification is linear and thus, do not reject null hypothesis $\mathrm{H} 0$ which states the model specification is correct.

The linear function for the study regression equation is denoted as below;

$\mathrm{DEPGR}=-0.012-0.737 \mathrm{ADR}+0.153 \mathrm{BRE}+0.066 \mathrm{BAS}+17.593 \mathrm{UNE}-6.795 \mathrm{POP}+0.325 \mathrm{INF}+1.073 \mathrm{M} 2$

In the below table the fixed effect panel data regression results show the coefficient intercept $(\alpha)$ is -0.012 . This means, when all explanatory variables took a value of zero, the average value deposit growth would take 0.012 showing holding all the other independent variables constant, a one-unit increase in independent variable cause 0.012 decrease in deposit.

\section{Regression result}

Dependent Variable: DEPGR

Method: Panel Least Squares

Date: 05/04/21 Time: 00:50

Sample: 20102019

Periods included: 10

Cross-sections included: 8

Total panel (balanced) observations: 80

\begin{tabular}{ccccc}
\hline \hline Variable & Coefficient & Std. Error & t-Statistic & Prob. \\
\hline \hline C & -0.012480 & 0.460944 & -0.027076 & 0.9785 \\
ADR & -0.737907 & 0.257768 & -2.862681 & $0.0056^{* * *}$ \\
BRE & 0.153870 & 0.077897 & 1.975313 & $0.0525^{*}$ \\
BAS & 0.066166 & 0.038084 & 1.737360 & $0.0871^{*}$ \\
UNEM & 17.59382 & 22.85375 & 0.769844 & 0.4442 \\
POP & -6.795054 & 2.225808 & -3.052848 & $0.0033^{* * *}$ \\
M2 & 1.073762 & 0.283291 & 3.790321 & $0.0003^{* * *}$ \\
INF & 0.325426 & 0.132918 & 2.448327 & $0.0171^{* *}$
\end{tabular}

Effects Specification

Cross-section fixed (dummy variables)

R-squared

Adjusted R-squared

S.E. of regression

Sum squared resid

Log likelihood

F-statistic

Prob(F-statistic)
0.720224 Mean dependent var

0.659964 S.D. dependent var

0.082045 Akaike info criterion

0.437537 Schwarz criterion

94.82972 Hannan-Quinn criter.

11.95204 Durbin-Watson stat
0.272679

0.140698

$-1.995743$

$-1.549113$

$-1.816676$

2.256570

$\mathrm{R}^{2}$ tell us how much variation in the dependent variable is accounted for by the regression model. Moreover, the adjusted R-Squared value tells us how much variance in the dependent variable would be accounted for if the model had been derived from the population from which the sample was taken. Specifically, it reflects the goodness of fit of the model to the population taking into account the sample size and the number of predictors used (Brooks, 2014). Here, in this study, R-squared coefficient of 0.720224 has been obtained from the estimated regression model shows strong explanatory power of the model. In addition, the adjusted $\mathrm{R}^{2}$ of $65.99 \%$ indicates that the model is strongly fit for predicting the deposit growth of commercial banks in Ethiopia. This indicates 
that $65.99 \%$ of changes that occur in the dependent variable deposit growth are attributable to the independent variables. The above table shows ADR affect DEPGR negatively at statistical significance level of $1 \%$. Based on the beta coefficient (-0.7379) of ADR holding other things constant; if ADR increase by one unit, commercial banks' DEPGR decrease by 0.7379 . This implies that; the overall capacity for deposit of banks to grow is reduced because the large number of the young and the older people burden the economy. As indicated from the above table branch expansion has a positive in its relationship with the commercial banks deposit growth and it is statistically significant even at $10 \%$ significance level. This result implies that deposit growth increases when number of branch increases. The coefficient of 0.1538 revealed that, taking other independent variables constant, a 1 percent change in branch expansion rate leads to a 0.1538 unit change in deposit growth of commercial banks in Ethiopian. The expansion of new branch is helpful to get many customers particularly those in far remote areas by which banking service is not addressed. As the branch of commercial banks were expanded all over the nation, peoples tends to save their idle cash or some of their wealth in the form of deposit/saving or commercial banks can easily collect available financial resource (deposit). With regard to bank size the coefficient 0.066 indicates that holding other things constant if one-unit increase in bank size increase the deposit of commercial banks in Ethiopia by 0.066 . The above result shows that bank size has a positive and statistically significant effect (at 10\%) on the deposit growth of commercial banks in Ethiopia. This indicates that larger banks with economies of scale and a larger branch network are more efficient in collecting deposit deposits than smaller banks. The above table shows there is a Positive and insignificant relationship between Unemployment rate and deposit growth in Ethiopia ( $\mathrm{P}$-value=0.4442). unemployment rate measures the number of unemployed people from the total labour force. Understanding the behaviour of remittances, one can estimate that the respective families invest a portion of remittances in savings deposits; while the rest for consumption. Population growth rate has a $p$ - value of 0.0033 which shows it is statistically significant at $1 \%$ and the coefficient -6.795 shows negative impact of population growth rate on deposit of commercial banks in Ethiopia. Thus, other things remain unchanged a 1 percent change in population growth leads to -6.795 units change in deposit growth of commercial banks in Ethiopia. This is due to population growth produces large proportions of children and youth relative to the labour force. Families spend far more on children than the children can quickly repay in economic production, especially as modern schooling and health care replaces child labour so It is expected consumption related to children to retard household savings. On the other hand, the coefficient 1.073 reflects that an increase of 1 unit in broad money growth rate may increase banks deposit growth rate by 1.073 units and vice versa. The $\mathrm{p}$ - value of 0.0003 indicates that broad money supply significantly (at 1\%) affect deposit growth of commercial banks in Ethiopia. The results show a significant positive effect of broad money supply on deposit growth. This suggests that bank deposit growth is affected by a percentage increase in money supply. The result reflects the hypothesis that money supply evaluates monetary conditions, and bank deposit growth manifests the growth in money supply. This shows that inflation had positive and statistically significant effect on deposit growth of commercial banks. This indicates that a change in inflation by 1 percent leads to a change in deposit growth of commercial banks by 0.325 units. However, different studies showed varying results regarding the directional relationship between inflation and deposit growth. precautionary saving increase at the increase of inflation up to certain point. This may be due to lack of entrepreneur skill of the society and lack of other alternative investments in the country or may be the risk-averse mentality of most depositors. This finding supports the Precautionary theory of saving, Classical interest rate theory and Neo-Classical Growth Theory which state inflation has positive effect on deposits.

\section{Conclusion}

Age dependency ratio has a negative and significant relationship with deposit growth. This means that a higher old age or youth dependency ratio will allows to consume those incomes generated so, saving will decline. The result shows that commercial banks branch expansion had positive and significant effect on deposit growth of commercial banks in Ethiopia. This result indicates that increase in number of bank branch will increase the accessibility of banking service, therefore the more banks accessible the more customers will access and as the same time the more deposits were collected. Bank size which is proxy of logarithm of total asset of commercial banks had a positive and significant effect on deposit growth of commercial banks in Ethiopia. This result indicates that larger banks with economies of scale and a larger branch network are better in collecting deposit deposits than smaller banks. Population growth of the country has a negative and significant impact on the deposit growth of commercial banks in Ethiopia. This result shows as the number of population grows fast the consumption grows in the same direction so deposit in banks can decline. With regard to broad money supply which is proxy of annual change in broad money supply had a positive significant effect on deposit growth of commercial banks in Ethiopia as it is summation of currency in circulation, demand deposit, time deposit and saving deposit. Annual Inflation Rate had a positive and significant effect on deposit growth of commercial banks in Ethiopia. It implies the theory of standard life cycle and neo-classical growth theory; inflation could influence deposit/savings through its impact on real wealth. If customers attempt to maintain a target level of 
wealth or liquid assets relative to their income, they will increase their savings, as the same time commercial banks deposit will raise with the rise in inflation.

\section{Recommendations}

$>$ The population growth in the country is diverting the scarce capital away from savings/deposit. So the concerned body should educate people about family planning and incorporate population growth and family planning into political and economics courses in high school and college and incorporate population control into national economic plans. additionally, the government should establish a permanent population committee to plan, develop, and implement population policies and related research in order to boost level of saving in the nation.

$>$ commercial banks should increase ways to approach and mobilize the huge deposits lying in the unbanked society to maximize and maintain their portfolios.

$>$ NBE should continuously control the money supply by looking for the reserve requirement of banks, applying the expansionary and the contractionary policies in order to control the level of money supply.

$>$ Policy makers should continuously control inflation in order to boost the growth of deposit through commercial banks in Ethiopia. Increase in inflation up to the point which enhance the growth in economy can increase the level of deposits. However, uncontrolled inflation may retard economic growth and then deposit growth of commercial banks.

\section{Suggestion for further studies}

This study has been focused on some macro-economic and bank specific determinants of deposit growth in ten sampled commercial banks over 2010-2019 in Ethiopia. Therefore, future researchers who want to conduct their study in the same topic are recommended to include or examine factors which did not studied under this study such as saving habit of households towards using banking services of commercial banks, level of education and dependency ratio of the population and consumption of households identified by some literatures to have impact on deposit growth of commercial banks. Thus, a study has to be further strengthened on the significance of these factors on deposit growth of commercial banks. The researcher also recommends future researchers to take in to consideration about primary data that strengthen the findings of secondary data.

\section{References}

Abebe, S. (2017). Factors Affecting Banks’ Deposit Growth - A case Commercial Bank of Ethiopia (CBE). AAU.

Admas, J. T., Robert, R., and White, D. (2007). Research Methods for Graduate Business and Social Science Students.

Ambe, E.M. (2017). An Investigation of Determinants of Deposit Mobilization in Commercial Banks of Ethiopia Research on Humanities and Social Sciences.55-64

Ando, A. and Modigliani, F. (1963). The" life cycle" hypothesis of saving: Aggregate implications and tests. The American Economic Review, 53, 55-84.

Ayalew, H. A. 2013. Determinants of domestic saving in Ethiopia: An autoregressive distributed lag (ARDL) bounds testing approach. Journal of Economics and International Finance, 5, 248

Aziza Hashi Abokor, I. a. (2020). Factors determining bank deposit growth in Turkey:an empiricalanalysis . Emerald Publishing, 122-132.

Bargicho, S. (2015). DETERMINANTS OF COMMERCIAL BANK DEPOSITS IN ETHIOPIA: A CASE OF COMMERCIAL BANK OF ETHIOPIA. Addis Ababa University.

Bhalla, V. K. (2006). Financial Management and Policy, New Delhi, Anmol Publications, Pvt. Ltd.

Bhatt, V. V. (1970). Some Aspects of Deposit Mobilization" Economic and Political Weekly, Economic and Political Weekly. Vol. 5, No. 36, pp. 1495-1497

Bhattacherjee, A. (2012). Social Science Research: Principles, Methods, and Practices: University of South Florida, scholar commons, 1-159

Brooks, C. (2008). Introductory Econometrics for Finance (Second ed.). New York: Cambridge University Press.

Carlson, M. and Mitchener, K.J. (2005). Branch Banking, Bank Banking Competition, and Financial Stability. National Bureau of Economic Research

Creswell, J. W. (2009). Research Design: Qualitative, Quantitative, and Mixed Methods Approaches. California: Sage Publications Inc

Deaton, A. (1991). Saving and Liquidity Constraints', Econometrica. New working series, 1221-1248.

Demirgüç-Kunt, A., and Huizinga, H. (1999). Determinants of commercial bank interest margins and profitability: some international evidence. The World Bank Economic Review, 13 (2), 379-408. Determination in an Error Correction Model

Duesenberg. (1949). Relative Income Hypothesis (RIH). Theories of Savings 
Epaphra, M. (2014). Empirical Investigation of the Determinants of Tanzania's National Savings. Journal of Economics and Development Studies, 2, 223-241.

ERNA, R., and EKKI, S. (2004). Factors Affecting Mud Araba Deposits in Indonesia. Working Paper in Economics and Development Studies. Padjadjaran University of Indonesia.

FDIC. (2010). The Effect of Banking Crises on Deposit Growth: State-Level Evidence from 1900 to 1930. FDIC Center for Financial Research Working Paper, 1-33.

Ferrouhi. E. M, Determinants of bank deposits in Morocco, Maghrep Rev. Econ. Manage. 4 (1) (2017) 23-26.

Friedman. (1957). Permanent Income Hypothesis (PIH) . Theory of savings.

Gebre, T. (2019). Determinants of Private Commercial Banks' Deposit Growth in Ethiopia . AAU, 1-49.

Geda, A. (2015). Will the Government of Ethiopia's policy of saving mobilization be successful? The lesson from the African Evidence, 5(2).

Geda, T. A. (August 2001). Ethiopia's New Financial Sector and Its Regulation.

Gerawerk, k. (2016). Determinants of commercial banks deposit mobilization. 1-58.

Gujarat, D. (2004). Basic Econometric, 4th ed. USA, Mc Graw Hill.

Gunasekar, H. U., and Kumari, P. (2018). Factors Affecting for Deposit Mobilization in Sri Lanka. International Review of Management and Marketing, 30-42.

Harold, L. S. (1946). The Problem of Excessive Commercial Bank Earnings.Oxford University Press. The Quarterly Journal of Economics, Vol. 60, No. 3, pp. 365 -389.

Haron, S., and Wan, W. (2006). DEPOSIT DETERMINANTS OF COMMERCIAL BANKS IN MALAYSIA. Creating Dynamic Leaders, 3-17.

Herald, F., and Heiko, H. (2008). Herald, F., and HeikoLebanon-Determinants of commercial banks Deposits in a Regional Financial Center". IMF working paper.

I.N.Yakubu, and A.H.Abokor. (2020). Factorsdeterminingbankdeposit growthinTurkey:an empiricalanalysis. Emerald publishing, 122-132.

ILO. (2013). Resolution concerning statistics of work, employment and labour underutilization. . the 19th international conference of Labor Statisticians.

Islam, S. N., Ali, J., and Wafik, A. (2019). Determinants of Deposit Mobilization of Private Commercial Banks: Evidence from Bangladesh . International Journal of Business and Management Invention. Volume 8 Issue 10 Series, 26-33.

Jagadeesh, D. (2015). The Impact of Savings in Economic Growth: An Empirical Study Based on Botswana. International Journal, 10

James, and Tories. (2008). The roles of deposits in the banking sector; empirical studies in Malaysia. Journal of Finance and Economics, 2(1).

JIM, S. (2008). How-To" Guide: Finding and Interpreting GDP Statistics" Canadian Centre for Policy alternatives. , . Journal of Economics, 44-51.

Kaufman, G. (1972). Deposit Variability and Bank Size. . The journal of financial and pp quantitative analysis, 2087-2096.

Khalily.M. A., M. a. (1987). Deposit Mobilization in Bangladesh : Implications for Rural Financial Institutions and Financial Policies. Bangladesh Institute of Development Studies, 85-117.

KOUL, L. (2006). Methodology Of Educational Research, 5th, Vikas Publishing House Pvt Ltd.

Lorenzo. C, Arjan. K, Christoffer. K, Sorensen and Macro. P (2010) "Do Bank Loans and Credit Standards Have an Effect on Output? A Panel Approach for Euro Area” Working Paper Series, European Central Bank

M. A. Baqui, K., and Richard L. Meyer, L. J. (1987). Deposit Mobilization in Bangladesh : Implications for Rural Financial Institutions and Financial Policies. The Bangladesh Development Studies, Vol. 15, No. 4, pp 85-117.

Malhotra, N. (2007.). Marketing Research: An applied Orientation, 5th Edition. New Delhi

Mahdi, and mohammed. (2010). The determinantes of savings Mobilization; an emiperical evidence in Italy. . Journal of Finance and Investmen.

Mahendra, V. P. (2005). "Impact of Self-Help Groups on Formal Banking Habits" , No. 17. Economic and Political Weekly. Vol. $40,17,1705-1713$.

Maria, S. M., and Sergio, L. S. (2001). Do Depositors Punish Banks for Bad Behavior? Market Discipline, Deposit Insurance, and Banking Crises. The Journal of Finance, Vol. 56, No. 3, pp. 1029-1051.

Mark, C., and Kris, J. M. (2006). Branch Credit Banking, Bank Banking Competition, and Financial Stability. Ohio State University,. Journal of Money and Vol. 38, No. 5 , pp. 12931328.

Mogesie, F. (2019). Determinants of Deposit in Ethiopian Private Commercial Banks. AAU, 1-70.

Mushtaq, S. and Siddiqui, D. A.(2017), "Effect of interest rate on bank deposits: Evidences from Islamic andnon-Islamiceconomies",FutureBusinessJournal,Vol.3No.1,pp.1-8.

Nathnael, O. (2014). Macroeconomic Determinants of Bank Deposits in Nigeria, ISSN 2222-1700 (Paper) ISSN 2222-2855 (Online) Vol.5, No.10, 2014. Journal of Economics and Sustainable Development. 
Nishat, M., and Bilgirami, N. (1989). DETERMINANTS OF GROWTH OF BANK DEPOSITS IN PAKISTAN. Giordano Dell-Amore Foundation , 391-400.

Opoku, s. (2011). MOBILIZING DEPOSITS; THE ROLE OF COMMERCIAL BANKS IN GHANA . Kwame Nkrumah University of Science and Technology.

Osei,L.K, Determinants of Rural Banks Deposit Mobilization in Ghana (Dissertation (Masters)), Kwame Nkrumah University of Science and Technology, Ghana, 2016.

Pitonakova, R. (2016). Determinants of Household Bank Deposits: Evidence from Slovakia. journal of Economics, Business and Management, 528-533.

Pradhan, R., and Paneru, D. (2014). Macroeconomic determinants of bank deposit of Nepalese commercial banks . 9-14.

Rachmawati, E. and Syamsulhakim, E. (2004). Factors Affecting Mudaraba Deposits in Indonesia. Working Paper in Economics and Development Studies. Padjadjaran University of Indonesia

Rao, d. (1975). Deposit Mobilization by Co-operative Banks. Comparison Economic and Political Weekly, 1098-1100 .

Rauch, C., Steffen, S., Hackethal, A. and Tyrell, M. (2008). Determinants of bank liquidity creation, Evidence from savings banks. Working paper. Germen.

Ho, T. S., and Saunders, A. (1981). The determinants of bank interest margins: theory and empirical evidence. Journal of Financial and Quantitative analysis, 16 (04).

Sheku, A. B. (2005). "Statistical Information and the Banking Sector" For Presentation at the Fourth meeting of the Committee on Development Information (CODI-IV)-Sub-Committee on Statistics, Plenary Session 1:Information in Key Economics Sector, United Nations Conference Centre.

Siaw, O. L., and Lawer, P. A. (2015). Determinants of Bank Deposits in Ghana: A Cointegration Approcah. Asian Journal of Economics and Empirical Research, 1-7.

Sibusiso, M., Yinusa, D., and Fransis, N. (2011). Sibusiso, M. K., Yinusa, D. O., and Francis, N. (2011). Determinants of Commercial Bank Interest Rate Margins in Swaziland. International Journal of Economics and Business Studies.

Simegnew, m. (2020). determinants of deposit growth. an emperical study on Ethiopian private commercial banks. bahirdar university, 1-57.

Teshome, F. (2017). Determinants of Commercial Banks Deposit in Ethiopia. AAU, 1-73.

Tochukwu, Nwachukwu, and Peter. (2009). The determinants of private saving in Nigeria. Journal of Investment and Finance, 20-23

Turhani, A., and Hoda, H. (2016). The Determinative Factors of Deposits Behavior in Banking System in Albania. Academic Journal of Interdisciplinary Studies MCSER Publishing, Rome-Italy, 246-256.

Yanne .G, P., Schepelmann, H. and Sand, I. V. D. (2007). Alternative Progress indicators to Gross Domestic Product(GDP) as a means towards sustainable development. European Parliament

Yakubu, I. N., and Abokor, A. H. (2020). Factorsdeterminingbankdeposit growthinTurkey:an empiricalanalysis. Emerland publishing, 122-132. 